RASĀYAN J. Chem.

Vol. 12 | No. 4 |2311 - 2317| October - December | 2019 ISSN: 0974-1496 | e-ISSN: 0976-0083 | CODEN: RJCABP

RJC http://www.rasayanjournal.com http://www.rasayanjournal.co.in

\title{
SYNTHESIS AND CRYSTALLOGRAPHIC STRUCTURE ANALYSIS OF 4,4'-OXYDIANILINE
}

\author{
G. Sharma ${ }^{1}$, S. Anthal ${ }^{1}$, D. V. Geetha ${ }^{2}$, F. H. Al-Ostoot ${ }^{3,4}$, M. Q. A. Al- \\ Gunaid $^{5}$, S. A. Khanum ${ }^{3}$, M. A. Sridhar ${ }^{2}$ and R. Kant ${ }^{1 *}$ \\ ${ }^{1}$ X-ray Crystallography Laboratory, Department of Physics, University of Jammu, \\ Jammu Tawi-180006, India. \\ ${ }^{2}$ Department of Studies in Physics, Manasagangotri, University of Mysore, \\ Mysuru-570005, India. \\ ${ }^{3}$ Department of Chemistry, Yuvaraja's College, University of Mysore, Mysuru-570005, India. \\ ${ }^{4}$ Department of Biochemistry, Faculty of Education \& Science, University of Albaidha, Yemen. \\ ${ }^{5}$ Department of Polymer Science and Technology, \\ JSS Science \& Technology University, Mysuru, India. \\ *E-mail: rkant.ju@gmail.com
}

\begin{abstract}
The title compound, 4,4'-Oxydianiline, was synthesized in good yield by the reaction of 4-fluoro nitrobenzene with 4-nitrophenol in dimethylacetamide (DMAc) and toluene at $165{ }^{\circ} \mathrm{C}$ for $4 \mathrm{~h}$ in the presence of $\mathrm{K}_{2} \mathrm{CO}_{3}$ to obtain 4,4 'dinitrodiphenyl ether, which was then treated with $\mathrm{Pd} / \mathrm{C}$ in $\mathrm{N}, \mathrm{N}$-dimetyl formamide (DMF) at $65{ }^{\circ} \mathrm{C}$ for $12 \mathrm{~h}$. The crude product was recrystallized and elucidated by spectroscopic techniques (H NMR, LC-MS), elemental analyses. The compound crystallizes in the orthorhombic crystal system with space group $\mathrm{P} 2{ }_{1} 2_{1} 2_{1}$ with unit cell parameters: a $=5.7203(10) \AA, b=7.7326(14) \AA, c=22.8219(42) \AA$ and $Z=4$. The crystal structure has been solved by using direct methods and refined by full-matrix least squares procédures to a final R-factor of 0.028 for 1835 observed reflections. The structure exhibits intermolecular $\mathrm{H}$-bonds of the type $\mathrm{N}-\mathrm{H} \cdots \mathrm{O}$ and $\mathrm{N}-\mathrm{H} \cdots \mathrm{N}$. N-H $\cdots \pi$ interactions are also observed in the structure.
\end{abstract}

Keywords: X-ray Diffraction, Direct Methods, Intermolecular interactions, Crystal, Synthesis.

(C) RASĀYAN. All rights reserved

\section{INTRODUCTION}

The use of aromatic amines in the production of polyimide films has led to the development of different materials with great potential for commercial applications such as lightweight batteries, light-emitting diodes $^{1}$, capacitors ${ }^{2}$, electrochromic devices ${ }^{3,4}$ and optoelectronic devices ${ }^{5}$, and high temperature resistant products. ${ }^{6,7}$ Conducting ODA polymer films have found application in the field of bio-sensors and bioelectrochemistry. ${ }^{8,9}$ Polyaromatic compounds have been reported to show high biological activity, for example polyaromatic hydrocarbons are considered to be one of the robust antitumor agents. ${ }^{10-12}$ In view of its wide range of biological properties and as part of our ongoing work ${ }^{13-15}$ the synthesis and characterization of the title compound was carried out.

\section{General}

\section{EXPERIMENTAL}

All solvents and reagents were purchased from Sigma Aldrich Chemicals Pvt Ltd. TLC was performed on aluminum-backed silica plates and visualized by UV-light. Melting points were determined on an electrically heated VMP-III apparatus. The elemental analyses of the compounds were performed on a Perkin Elmer 2400 elemental analyzer. The ${ }^{1} \mathrm{H}$ NMR spectra were recorded on VNMRS-400 AgilentNMR spectrophotometer in DMSO. Chemical shifts are given in parts per million downfield from tetramethylsilane.

Rasayan J. Chem., 12(4), 2311-2317(2019)

http://dx.doi.org/10.31788/RJC.2019.1245305

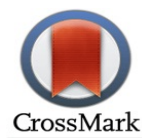


RASĀYAN J. Chem.

Vol. 12 | No. 4 | 2311 - 2317| October - December | 2019

The mass spectra were obtained with a VG70-70H spectrophotometer and the elemental analysis $(\mathrm{C}, \mathrm{H})$ was performed on Elementar Vario EL III elemental analyzer. The results of elemental analyses are within $\pm 0.5 \%$ value.

\section{Synthetic Procedure for 4,4'-Dinitrodiphenyl Ether (3)}

In a round-bottomed flask containing a mixture of 4-fluoro nitrobenzene (1, $10.7 \mathrm{~g}, 49.3 \mathrm{mmol}), 4$ nitrophenol (2, $6.85 \mathrm{~g}, 49.3 \mathrm{mmol}),(6.80 \mathrm{~g}, 49.3 \mathrm{mmol})$ of potassium carbonate, $150 \mathrm{~mL}$ of dimethylacetamide (DMAc) and $25 \mathrm{~mL}$ of toluene was stirred at $130{ }^{\circ} \mathrm{C}$ for $2 \mathrm{~h}$. The temperature of the reaction was then raised to $165{ }^{\circ} \mathrm{C}$, and the mixture was stirred at this temperature for $4 \mathrm{~h}$. The reaction mixture was cooled to $85^{\circ} \mathrm{C}$, and the solvent under reduced pressure of $15-25$ torr was evaporated. The residue was washed with $200 \mathrm{~mL}$ of water and the compound (3) was obtained by recrystallization from acetic acid.

\section{Synthetic Procedure for 4,4'-Diaminodiphenyl Ether (4)}

A mixture of $(3,10.50 \mathrm{~g}, 31.2 \mathrm{mmol})$ and $(0.3 \mathrm{~g}, 10 \%)$ of $\mathrm{Pd} / \mathrm{C}$ in $150 \mathrm{~mL}$ of $N, N$-dimetyl formamide (DMF) was stirred at $65{ }^{\circ} \mathrm{C}$ for $12 \mathrm{~h}$ under hydrogen atmosphere. The $\mathrm{Pd} / \mathrm{C}$ was then removed by filtration; the solvent was evaporated under reduced pressure of 15-20 torr and the title compound (4) was then obtained by distillation under reduced pressure as shown in Fig.-1. Schematic of H NMR and LCMS spectra are shown in Fig.-2 and 3, respectively.<smiles>N#Cc1ccc(F)cc1O</smiles><smiles>O=[N+]([O-])c1ccc(O)cc1</smiles>

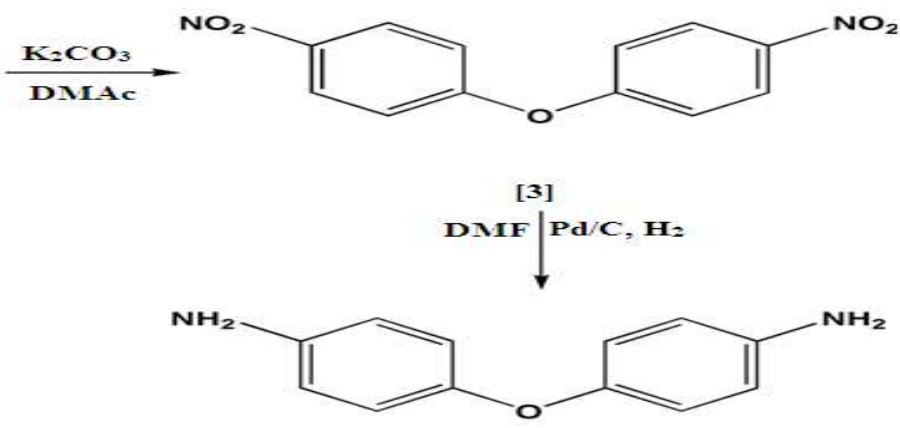

[4]

Fig.-1: Schematic Representation of The Synthesis of The Title Compound (4).

\section{Spectral Data for 4,4'-dinitrodiphenyl ether (3)}

Yield 80\%; M.P. $140-145{ }^{\circ} \mathrm{C}$; ${ }^{1} \mathrm{HNMR}\left(400 \mathrm{MHz}, \mathrm{DMSO}^{-} \mathrm{d}_{6}\right) \delta(\mathrm{ppm}): 7.21-8.27$ (m, 8H, Ar-H); LC-MS m/z: $261[\mathrm{M}+1]$. Anal. Calcd. for $\mathrm{C}_{12} \mathrm{H}_{8} \mathrm{~N}_{2} \mathrm{O}_{5}(260)$ : C, 55.39; H, 3.10; N, 10.77. Found: C, 55.31; H, $3.04 ; \mathrm{N}, 10.70 \%$.

\section{Spectral Data for 4,4'-oxydianiline (4)}

Yield 85\%; M.P. $187-191{ }^{\circ} \mathrm{C}$; ${ }^{1} \mathrm{HNMR}\left(400 \mathrm{MHz}, \mathrm{DMSO}-\mathrm{d}_{6}\right) \delta(\mathrm{ppm}): 4.75\left(\mathrm{~s}, 4 \mathrm{H}, 2 \mathrm{NH}_{2}\right), 6.49-6.63(\mathrm{~m}$, 8H, Ar-H); LC-MS m/z: 201 [M+1]. Anal. Calcd. for $\mathrm{C}_{12} \mathrm{H}_{12} \mathrm{~N}_{2} \mathrm{O}$ (200): C, 71.98; H, 6.04; N, 13.99. Found: C, 71.88; H, 6.00; N, $13.89 \%$.

\section{X-ray Intensity Data Collection, Structure Solution And Structure Refinement}

X-ray intensity data of the crystal of dimensions $0.30 \times 0.20 \times 0.10 \mathrm{~mm}^{3}$ were collected on Bruker $A P E X 2$ CCD area-detector diffractometer ${ }^{16}$ equipped with graphite monochromated MoKa radiation $(\lambda=$ $0.710 \AA$ ). X-ray intensity data of 12684 reflections were collected at 293(2) $\mathrm{K}$ and out of these reflections 1964 were found unique. The intensities were measured by $\omega$ scan mode for $\theta$ ranges $1.79^{\circ}$ to $26^{\circ} .1835$ reflections with $\mathrm{I}>2 \sigma$ (I) were treated as observed. Data were corrected for Lorentz-polarization and absorption factors. The structure was solved by direct methods using SHELXS $97^{17}$ and was refined using SHELXL97. ${ }^{17}$ All non-hydrogen atoms of the molecule were located from the best E-map. All the 
RASĀYAN J. Chem.

Vol. 12 | No. 4 |2311 - 2317| October - December | 2019

hydrogen atoms were geometrically fixed (except $\mathrm{N} 1$ and $\mathrm{N} 2$ hydrogen atoms) and allowed to ride on their parent carbon atoms with $\mathrm{C}-\mathrm{H}=0.93-0.97 \AA$.

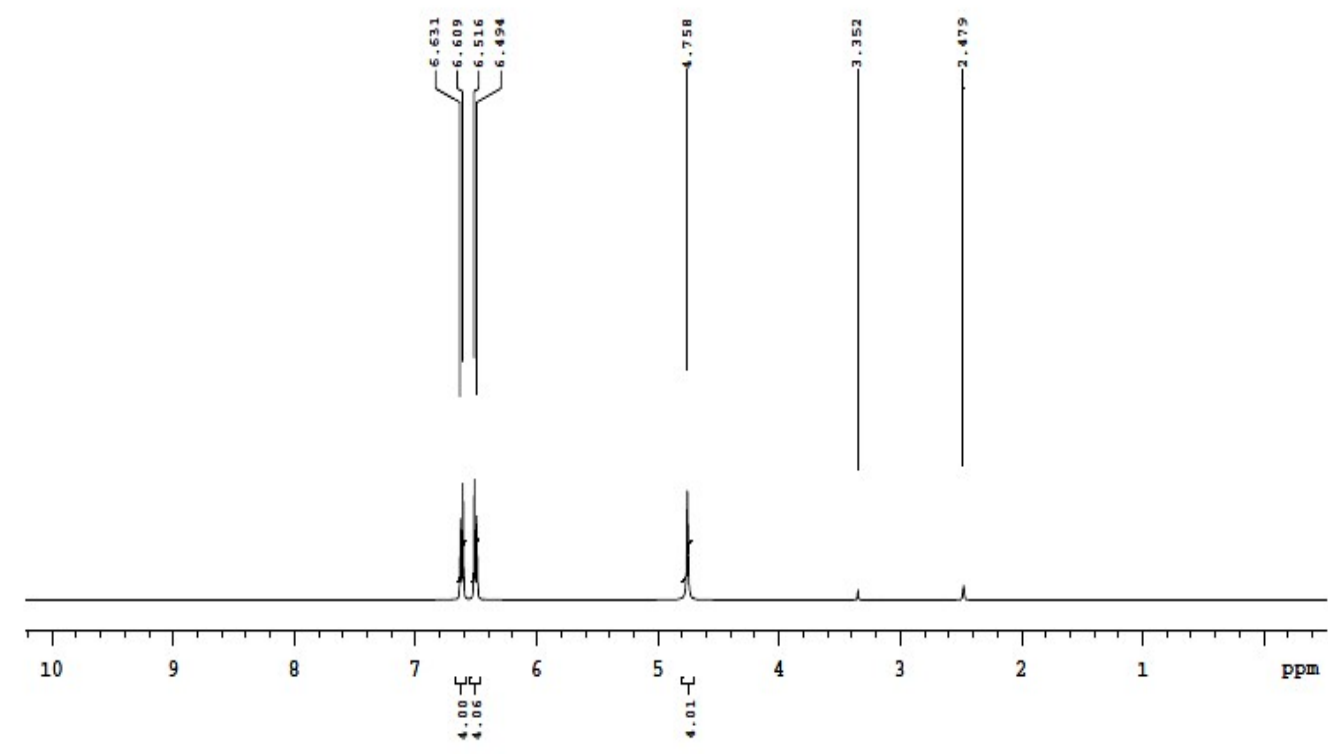

\begin{tabular}{|c|c|c|c|}
\hline \multirow{2}{*}{ 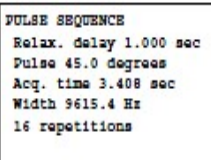 } & \multirow[t]{2}{*}{ OBgERVE $\quad$ \#1, 399.8276233} & \multirow{2}{*}{ 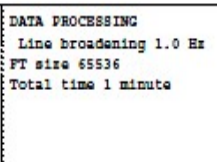 } & 1801822-789-1B \\
\hline & & & 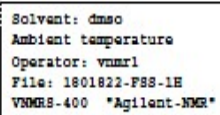 \\
\hline
\end{tabular}

Fig.-2: H NMR Spectrum of Compound (4).

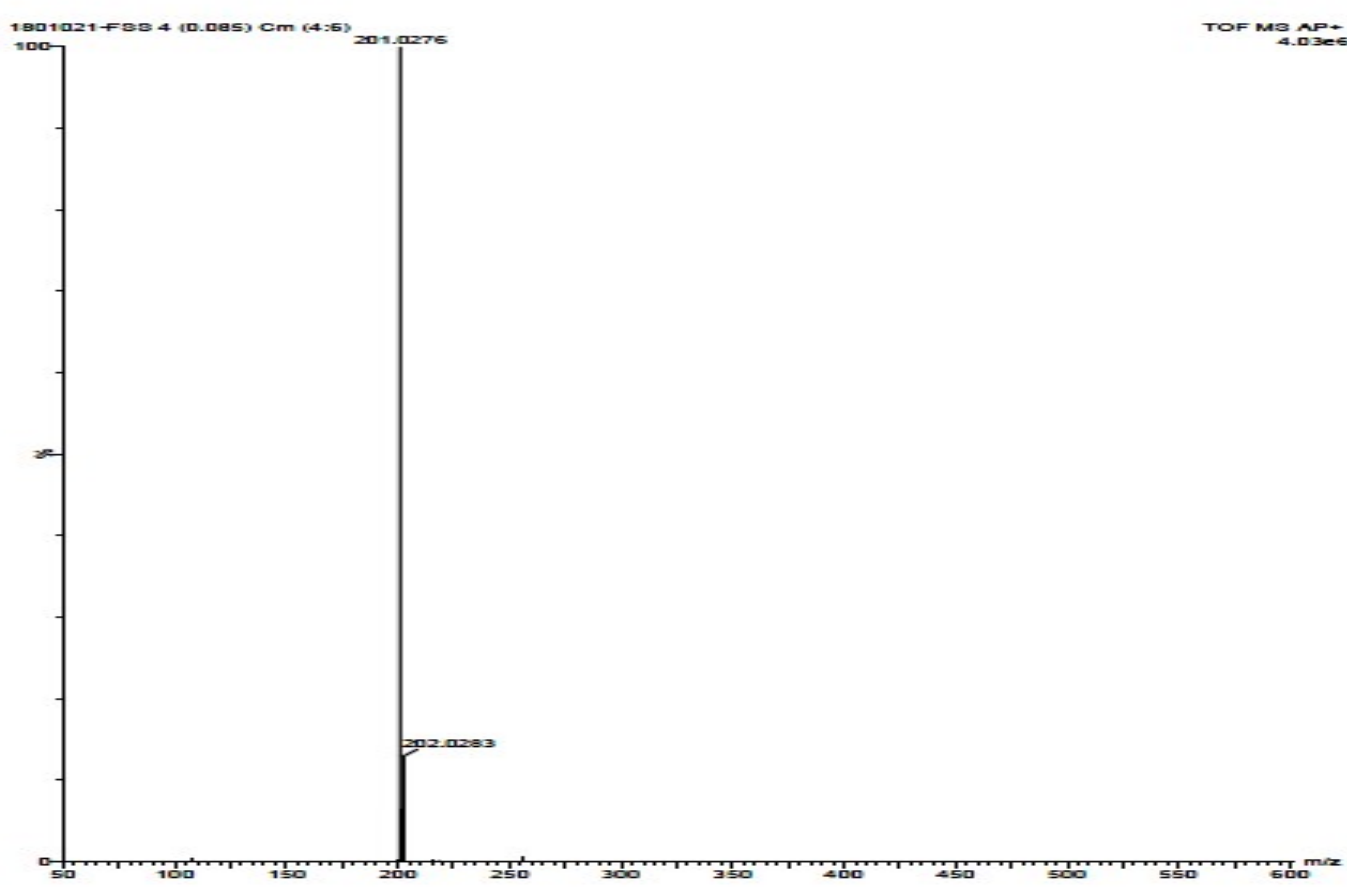

Fig.-3: LC-MS Spectrum of Compound (4).

The final refinement cycles converged to an R-factor of 0.028 and $w \mathrm{R}\left(\mathrm{F}^{2}\right)=0.075$ for 1835 observed reflections. Residual electron densities range from -0.13 to $0.13 \mathrm{e}^{-3}$. Atomic scattering factors were 
RASĀYAN J. Chem.

Vol. 12 | No. 4 | 2311 - 2317| October - December | 2019

taken from International Tables for X-ray Crystallography (1992, Vol. C, Tables- 4.2.6.8 and 6.1.1.4). The Geometry of the molecule was calculated using the WinGX ${ }^{18}$, PARST $^{19}$ and PLATON ${ }^{20}$ software. The crystallographic information file (CIF) has been deposited at the Cambridge Crystallographic Data Centre and the structure-refinement data is presented in Table-1.

Table-1: Crystallographic Characteristic and Structure-Refinement Data for $\mathrm{C}_{12} \mathrm{H}_{12} \mathrm{~N}_{2} \mathrm{O}$

\begin{tabular}{|c|c|}
\hline CCDC Number & 1906052 \\
\hline System, Space group, Z & Orthorhombic, $\mathrm{P} 2_{1} 2_{1} 2_{1}, 4$ \\
\hline$a, b, c(\AA)$ & $5.7203(10), 7.7326(14), 22.8219(42)$ \\
\hline $\mathrm{V}\left(\AA^{3}\right)$ & 1009.48 \\
\hline $\mathrm{D}_{\mathrm{x}}$ g. $\mathrm{cm}^{-3}$ & 1.32 \\
\hline Radiation, $\lambda, \AA$ & 0.71073 \\
\hline$\mu, \mathrm{mm}^{-1}$ & 0.09 \\
\hline $\mathrm{T}, \mathrm{K}$ & 293 \\
\hline Sample size, $\mathrm{mm}^{3}$ & $0.30 \times 0.20 \times 0.10$ \\
\hline Diffractometer & Bruker APEX-II CCD \\
\hline Scan mode & $\omega$ scan \\
\hline $\mathrm{T}_{\min }, \mathrm{T}_{\max }$ & $0.915,0.991$ \\
\hline$\theta$ range, deg & 1.78 to 25.99 \\
\hline$h, k, l$ ranges & $h=-7$ to $7, k=-9$ to $9, l=-28$ to 27 \\
\hline Reflections total/unique & $12684 / 1964$ \\
\hline Reflections observed $[\mathrm{I}>2 \sigma(\mathrm{I})]$ & 1835 \\
\hline $\mathrm{R}_{\text {int }}$ & 0.028 \\
\hline $\mathrm{F}(000)$ & 423.9 \\
\hline $\mathrm{R}$ & 0.028 \\
\hline$w \mathrm{R}\left[\mathrm{F}^{2}\right]$ & 0.075 \\
\hline$(\Delta / \sigma)_{\max }$ & 0.024 \\
\hline Number of refined parameters & 152 \\
\hline $\mathrm{S}$ & 1.035 \\
\hline$\Delta \rho_{\max }, \Delta \rho_{\min }\left(\mathrm{e} \AA^{-3}\right)$ & $0.13,-0.13$ \\
\hline Programs used & 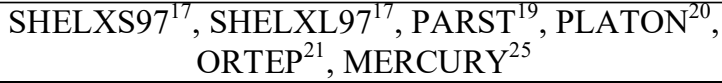 \\
\hline
\end{tabular}

\section{RESULTS AND DISCUSSION}

The molecular structure containing atomic labeling is shown in Fig.-4 (ORTEP). ${ }^{21}$ The molecular structure consists of two benzene rings which are essentially planar, with atom $\mathrm{C} 5$ and $\mathrm{C} 7$ displaced out of their mean ring planes by $-0.0071 \AA$ and $-0.0025 \AA$, respectively. Bond distances, bond angles and torsion angles which play an important role in collating the structural properties of the molecule are presented in Table-2.

Table-2: Bond Distances and Bond Angles.

\begin{tabular}{c|c|c|c}
\hline \multicolumn{2}{c|}{ Bond Distances $(\AA)$} & Bond Distances $(\AA)$ \\
\hline C1-C2 & $1.380(2)$ & C10-C & $1.3783(18)$ \\
\hline C3-C2 & $1.386(2)$ & C10-N2 & $1.3911(18)$ \\
\hline C4-C3 & $1.390(2)$ & C11-C10 & $1.4022(17)$ \\
\hline C5-C4 & $1.380(2)$ & C11-C12 & $1.3946(18)$ \\
\hline C6-C1 & $1.378(2)$ & N1-C3 & $1.3875(19)$ \\
\hline C6-C5 & $1.3752(18)$ & O1-C6 & $1.4002(15)$ \\
\hline C7-C8 & $1.3848(19)$ & O1-C7 & $1.3881(15)$ \\
\hline C7-C12 & $1.3738(18)$ & Bond Angles $\left({ }^{\circ}\right)$ \\
\hline Bond Angles $\left({ }^{\circ}\right)$ & $119.88(12)$ & C12-C7-C8 & $119.62(11)$ \\
\hline C6-C1-C2 & $120.97(13)$ & C12-C7-O1 & $123.36(12)$ \\
\hline
\end{tabular}


RASĀYAN J. Chem.

Vol. 12 | No. 4 |2311 - 2317| October - December | 2019

\begin{tabular}{c|c|c|c}
\hline $\mathrm{C} 2-\mathrm{C} 3-\mathrm{C} 4$ & $118.01(12)$ & $\mathrm{C} 9-\mathrm{C} 8-\mathrm{C} 7$ & $120.00(11)$ \\
\hline $\mathrm{N} 1-\mathrm{C} 3-\mathrm{C} 2$ & $121.28(15)$ & $\mathrm{C} 8-\mathrm{C} 9-\mathrm{C} 10$ & $121.41(12)$ \\
\hline $\mathrm{N} 1-\mathrm{C} 3-\mathrm{C} 4$ & $120.70(15)$ & $\mathrm{C} 9-\mathrm{C} 10-\mathrm{C} 11$ & $117.61(12)$ \\
\hline $\mathrm{C} 5-\mathrm{C} 4-\mathrm{C} 3$ & $121.37(13)$ & $\mathrm{C} 9-\mathrm{C} 10-\mathrm{N} 2$ & $121.43(12)$ \\
\hline $\mathrm{C} 6-\mathrm{C} 5-\mathrm{C} 4$ & $119.44(13)$ & $\mathrm{C} 11-\mathrm{C} 10-\mathrm{N} 2$ & $120.83(12)$ \\
\hline $\mathrm{C} 1-\mathrm{C} 6-\mathrm{C} 5$ & $120.31(12)$ & $\mathrm{C} 12-\mathrm{C} 11-\mathrm{C} 10$ & $121.03(11)$ \\
\hline $\mathrm{C} 1-\mathrm{C} 6-\mathrm{O} 1$ & $118.97(11)$ & $\mathrm{C} 7-\mathrm{C} 12-\mathrm{C} 11$ & $120.33(12)$ \\
\hline $\mathrm{C} 5-\mathrm{C} 6-\mathrm{O} 1$ & $120.63(12)$ & $\mathrm{C} 7-\mathrm{O} 1-\mathrm{C} 6$ & $117.07(9)$ \\
\hline $\mathrm{C} 8-\mathrm{C} 7-\mathrm{O} 1$ & $116.96(11)$ & & \\
\hline
\end{tabular}

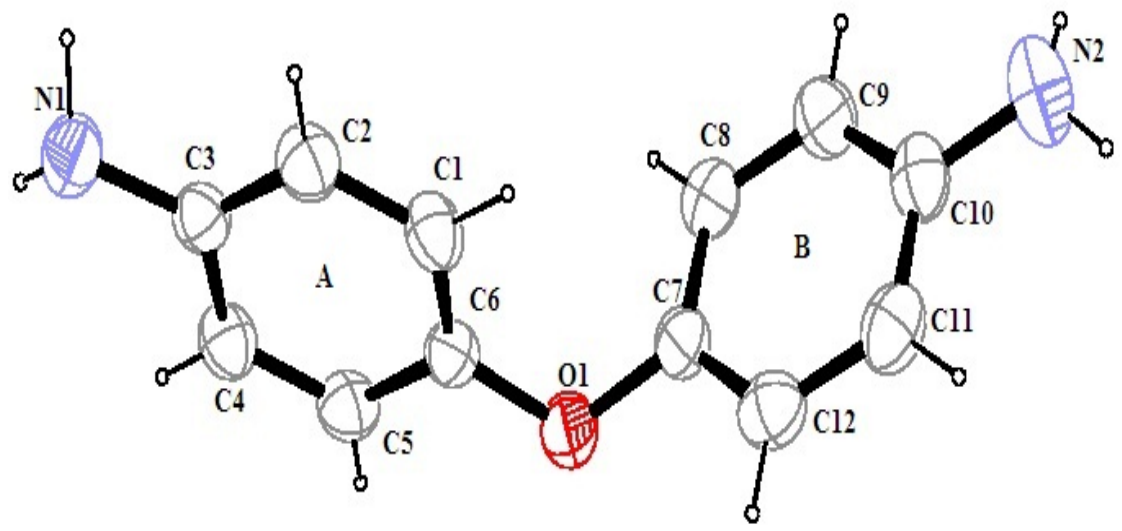

Fig.-4: Ortep View of The Molecule with Displacement Ellipsoids Drawn at The 40\% Probability Level. H Atoms Shown as Small Spheres of Arbitary Radii.

All the bond distances are in normal range ${ }^{22}$ (except $\mathrm{C} 3-\mathrm{N} 1$ and $\left.\mathrm{C} 10-\mathrm{N} 2\right)$ and are comparable with the values observed for some analogous structures. ${ }^{23,24}$ The C3-N1 [1.387(19) $\left.\AA\right]$ and C10-N2 [1.402(17) $\left.\AA\right]$ bond distance is smaller than the standard value of $1.470 \AA$. The benzene ring A makes a dihedral angle of $79.44^{\circ}$ with ring $\mathrm{B}$.

In the crystal structure, there exist two intermolecular hydrogen bonds $\mathrm{N} 2-\mathrm{H} 2 \mathrm{~A} \ldots \mathrm{O} 1$ and $\mathrm{N} 2-\mathrm{H} 2 \mathrm{~B} \ldots \mathrm{N} 2$, respectively [Fig.-5] (Mercury). ${ }^{25}$ Molecular packing in the unit cell as viewed down the a-axis is shown in Figure-6 (PLATON) ${ }^{20}$ The details of intra/inter-molecular hydrogen bonds are given in Table-3. The $\mathrm{N}-\mathrm{H} . . . \pi$ contacts as observed in the molecular packing are given in Table-4.

Table-3: Hydrogen Bonding Geometry (e.s.d.`s in parentheses)

\begin{tabular}{c|c|c|c|c}
\hline D-H...A & D-H $(\AA)$ & H...A $(\AA)$ & D...A $(\AA)$ & D-H...A $\left(^{\circ}\right)$ \\
\hline N2-H2A... O1 ${ }^{1}$ & 0.93 & 2.21 & $3.1299(6)$ & 170 \\
\hline N2-H2B...N2 ${ }^{\text {i1 }}$ & 0.91 & 2.37 & $3.2564(6)$ & 165 \\
\hline
\end{tabular}

Symmetry code: (i) x, $1+y, z$ (ii) $1 / 2+x, 3 / 2-y,-z$

Table-4: Geometry of N-H... $\pi$ Interactions*

\begin{tabular}{c|c|c|c|c}
\hline $\mathrm{D}-\mathrm{H} \ldots \mathrm{Cg}$ & $\mathrm{D}-\mathrm{H}(\AA)$ & $\mathrm{H} \ldots \mathrm{Cg}(\AA)$ & $\mathrm{D} \ldots \mathrm{Cg}(\AA)$ & $\mathrm{D}-\mathrm{H} \ldots \mathrm{Cg}\left(^{\circ}\right)$ \\
\hline $\mathrm{N} 1-\mathrm{H} 1 \mathrm{~A} \ldots \mathrm{Cg} 1^{\mathrm{i}}$ & 0.85 & 2.92 & $3.7045(7)$ & 153 \\
\hline $\mathrm{N} 1-\mathrm{H} 1 \mathrm{~B} \ldots \mathrm{Cg} 2^{11}$ & 0.86 & 2.78 & $3.6421(7)$ & 172 \\
\hline
\end{tabular}

Symmetry code: (i) $1-x,-1 / 2+y, 1 / 2-z$ (ii) $2-x,-1 / 2+y, 1 / 2-z$ 
RASĀYAN J. Chem.

Vol. 12 | No. 4 |2311 - 2317| October - December | 2019

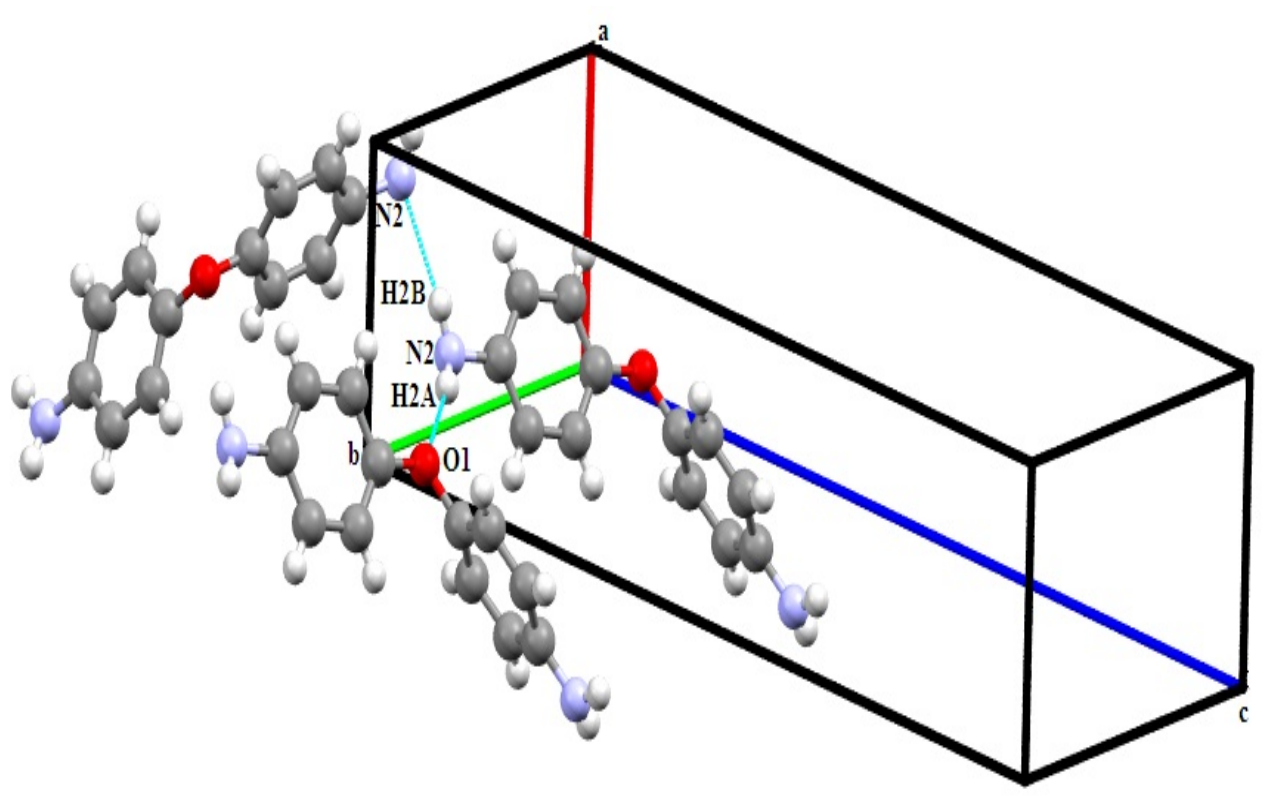

Fig.-5: Intermolecular Hydrogen Bonds Link The Molecule.

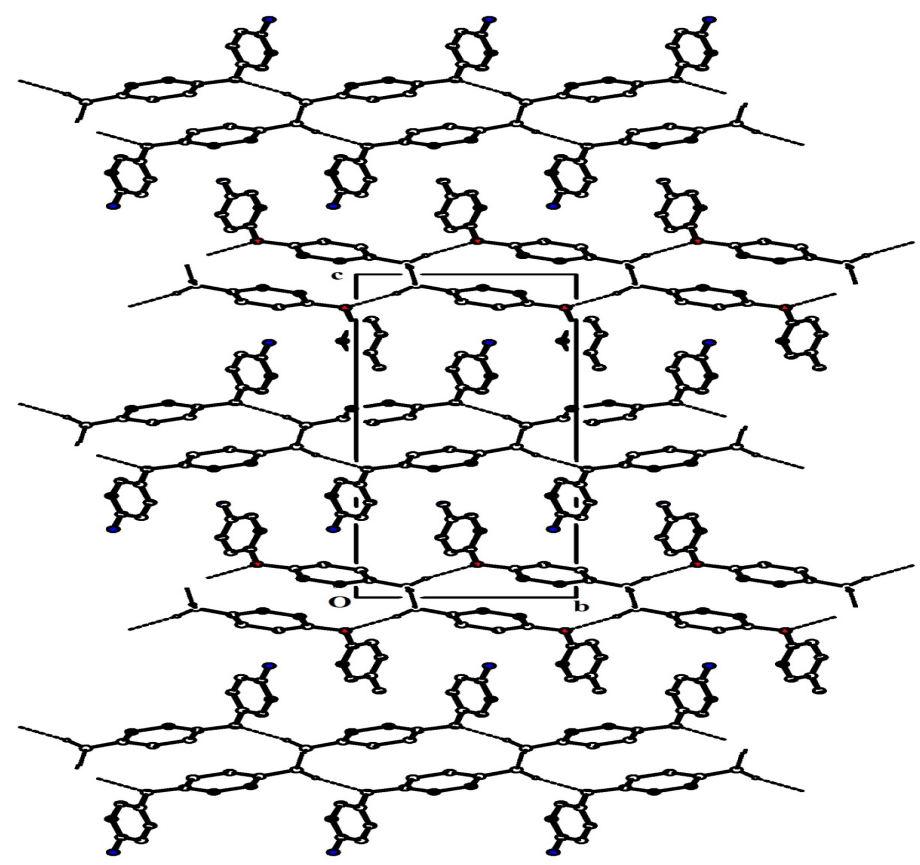

Fig.-6: Packing of The Molecules Viewed Down The A-Axis.

* Cg1 represent the centre of gravity of benzene(A) ring.

$\mathrm{Cg} 2$ represents the center of gravity of benzene(B) ring.

\section{ACKNOWLEDGMENT}

Rajni Kant is thankful to the Department of Science and Technology, New Delhi for funding under sponsored Research Project (No. EMR/2014/000467). Geetha thanks UGC-BSR for fellowship. Fares Hezam Al-Ostoot is thankful to the Government of Yemen and Albaidha University, Yemen, for providing financial assistance under the teacher's fellowship and the University of Mysore, Mysuru, India. Shaukath Ara Khanum thankfully acknowledges the financial support provided by VGST, Bangalore, under CISEE Program [Project sanction order: No. VGST/CISEE/282]. 


\section{REFERENCES}

1. P. K. H. Ho, J. Kim, J. H. Burroughes, H. Becker, S. F. Y. Li, T. M. Brown, F. Cacialli, and R. H. Friend, Nature, 404, 481 (2000), DOI: 10.1038/35006610.

2. S. Möller, C. Perlov, W. Jackson, C. Taussig, and S. R. Forrest, Nature, 426, 166 (2003), DOI: 10.1038/nature02070.

3. J. L. Boehme, M. S. K. Dhurjati and J. P. Ferraris, Chemistry of Materials, 13, 4469 (2001), DOI: $10.1021 / \mathrm{cm} 0103460$.

4. A. A. Argun, P. Aubert, B. C. Thompson, I. Schwendeman, C. L. Gaupp, J. Hwang, N. J. Pinto, D. B. Tanner, A. G. MacDiarmid, and J. R. Reynolds, Chemistry of Materials, 16, 4401 (2004), DOI: $10.1021 / \mathrm{cm} 0496691$.

5. G. D. Stucky, Nature, 410, 885 (2001), DOI: 10.1038/35073733.

6. National Toxicology Program, Bioassay of 4,4'-Oxydianiline for Possible Carcinogenicity (CAS No. 101-80-4), National Toxicology Program technical report series 205 (1980).

7. Human Papillomaviruses, IARC monographs on the evaluation of carcinogenic risks to humans, Lyon, France, IARC (2011).

8. J. D. Stenger-Smith, Progress in Polymer Science, 23, 57 (1998), DOI:10.1016/S00796700(97)00024-5.

9. D. T. McQuade, A. E. Pullen and T. M. Swager, Chemical Reviews, 100, 2537 (2000), DOI: 10.1021/cr9801014.

10. K. W. Bair, R. L. Tuttle, V. C. Knick, M. Cory and D. D. McKee, Journal of Medicinal Chemistry, 33, 2385 (1990).

11. F. F. Becker and B. K. Banik, Bioorganic \& Medicinal Chemistry Letters, 8, 2877 (1998), DOI: 10.1016/S0960-894X(98)00520-4.

12. K. W. Bair, C. W. Andrews, R. L. Tuttle, V. C. Knick, M. Cory, and D. D. McKee, Journal of Medicinal Chemistry, 34, 1983 (1991), DOI: 10.1021/jm00111a010.

13. M. K. Shankar, F. H. Al-Ostoot, B. C. Manjunath, S. V. Raghu, Y. H. E. Mohammed, N. Mahesh, A. K. Shaukath, N. K. Lokanath, and K. Byrappa, Journal of Molecular Structure, 1156, 216 (2018). DOI: 10.1016/j.molstruc.2017.11.094.

14. D. V. Geetha, F. H. Al-Ostoot, Y. H. E. Mohammed, M. A. Sridhar, S. A. Khanum, and N. K. Lokanath, Journal of Molecular Structure, 1178, 384 (2019), DOI: 10.1016/j.molstruc.2018.10.016.

15. S. M. Kumar, B. C. Manjunath, F. H. Al-Ostoot, M. Jyothi, M. Al-Ghorbani, S. A. Khanum, A. K. Kudva, N. K. Lokanath, and K. Byrappa, Chemical Data Collections, 15, 153 (2018), DOI: 10.1016/j.cdc.2018.05.003.

16. Bruker APEX2, SADABS, and SAINT. Bruker AXS Inc., Madison, Wisconsin, USA (2009).

17. G. M. Sheldrick, Acta Cryst., A64, 112 (2008), DOI:10.1107/S0108767307043930.

18. L. J. Farrugia, Journal of Applied Crystallography, 32, 837(1999), DOI: $10.1107 / \mathrm{S} 0021889899006020$.

19. M. Nardelli, Journal of Applied Crystallography, 28, 659(1995), DOI: 10.1107/S0021889895007138.

20. A. L. Spek, Acta Crystallographica, D65, 148 (2009), DOI: 10.1107/S090744490804362X.

21. L. J. Farrugia, Journal of Applied Crystallography, 30, 565(1997), DOI: 10.1107/S0021889897003117.

22. F. H. Allen, O. Kennard, D. G. Watson, L. Brammer, A. G. Orpen and R. Taylor, Journal of the Chemical Society Perkin Transactions, 2, $\quad$ S1 DOI:10.1039/P298700000S1.

23. M. Naz, Z. Akhter, V. McKee and A. Nadeem, Acta Cryst., E 69, o1747 (2003), DOI: $10.1107 / \mathrm{S} 1600536813029346$.

24. A. Nigar, Z. Akhter and M. N. Tahir, Acta Cryst., E68, o2485 (2012), DOI: $10.1107 / \mathrm{S} 1600536812031856$.

25. C. F. Macrae, P. R. Edgington, P. McCabe, E. Pidcock, G. P. Shields, R. Taylor, M. Towler, J. Van de Streek and P. A. Wood, J. Appl. Cryst., 41, 466 (2008), DOI: 10.1107/S0021889807067908.

[RJC-5305/2019] 